\title{
Phanerochaete porostereoides, a new species in the core clade with brown generative hyphae from China
}

\author{
Liu $\mathrm{SL}^{1}$ and $\mathrm{He} \mathrm{SH}{ }^{*}$ \\ ${ }^{1}$ Institute of Microbiology, Beijing Forestry University, Beijing 100083, China
}

Liu SL, He SH 2016 - Phanerochaete porostereoides, a new species in the core clade with brown generative hyphae from China. Mycosphere 7(5), 648-655, Doi 10.5943/mycosphere/7/5/10

\begin{abstract}
A new species, Phanerochaete porostereoides, is described and illustrated from northwestern China based on the morphological and molecular evidence. It is characterized by a effused brown basidiocarp, a monomitic hyphal system, yellowish brown generative hyphae without clamp connections, numerous hyphal ends in hymenium and subhymenium, and small ellipsoid basidiospores 4.7-5.3 × 2.5-3.1 $\mu \mathrm{m}$. Morphologically, P. porostereoides resembles Porostereum, but phylogenetic analyses inferred from the combined sequences of ITS and nLSU show that it is nested within the Phanerochaete s.s. clade, and not closely related to Porostereum spadiceum, type of the genus.
\end{abstract}

Key words - Porostereum - taxonomy - wood-inhabiting fungi

\section{Introduction}

Phanerochaete P. Karst., typified by Thelephora velutina DC., is a widespread genus, and characterized by the membranaceous basidiocarps, a monomitic hyphal system, simple-septate generative hyphae (single or multiple clamps may present in subiculum), clavate basidia and smooth thin-walled inamyloid basidiospores (Eriksson et al. 1978, Burdsall 1985, Bernicchia \& Gorjón 2010, Wu et al. 2010). Recent molecular research (de Koker et al. 2003, Wu et al. 2010, Floudas \& Hibbett 2015) show that Phanerochaete s.l. is polyphyletic and distributed across several lineages in the phlebioid and other clades of Polyporales. Most species of Phanerochaete have hyaline generative hyphae, but distinctly brown subicular hyphae present in several species, such as P. singularis (G. Cunn.) Burds. and P. stereoides Sheng H. Wu.

Two specimens with effused brown basidiocarps were collected by the senior author from temperate forest in Shaanxi Province, northwestern China, and at first they were identified as a member of Porostereum Pilát because of the yellowish brown generative hyphae and hyphal ends in hymenium and subhymenium. However, subsequent further morphological examination and phylogenetic analyses based on combined sequences ITS and nLSU showed that it should be placed in Phanerochaete and was new to science. It is described and illustrated as Phanerochaete porostereoides below.

\section{Materials \& Methods}

\section{Morphological studies}

Voucher specimens are deposited in the herbarium of Beijing Forestry University (BJFC). Samples for microscopic examination were mounted in cotton blue or $2 \%$ potassium hydroxide 
$(\mathrm{KOH})$. The following abbreviations are used: $\mathrm{L}=$ mean spore length, $\mathrm{W}=$ mean spore width, $\mathrm{Q}=$ $\mathrm{L} / \mathrm{W}$ ratio, $\mathrm{n}(\mathrm{a} / \mathrm{b})=$ number of spores (a) measured from given number of specimens $(\mathrm{b}), \mathrm{IKI}-=$ without reaction in Melzer's reagent, $\mathrm{CB}-=$ acyanophilous, Color codes and names are from Kornerup \& Wanscher (1978).

\section{DNA extraction and sequencing}

A CTAB rapid plant genomic DNA extraction Kit (Aidlab, Beijing, China) was used to extract total genomic DNA from dried specimens and perform the polymerase chain reaction (PCR), according to the manufacturer's instructions. The ITS and nLSU ribosomal RNA gene regions were amplified with the primer pairs ITS4 and ITS5 (White et al. 1990), and LR0R and LR7 (http://www.biology.duke.edu/fungi/mycolab/primers.htm), respectively. The PCR procedure for ITS was: initial denaturation at $95{ }^{\circ} \mathrm{C}$ for $4 \mathrm{~min}$, followed by 34 cycles at $94{ }^{\circ} \mathrm{C}$ for $40 \mathrm{~s}, 58{ }^{\circ} \mathrm{C}$ for $45 \mathrm{~s}$ and $72{ }^{\circ} \mathrm{C}$ for $1 \mathrm{~min}$, and a final extension at $72{ }^{\circ} \mathrm{C}$ for $10 \mathrm{~min}$, and for nLSU was: initial denaturation at $94{ }^{\circ} \mathrm{C}$ for $1 \mathrm{~min}$, followed by 34 cycles at $94{ }^{\circ} \mathrm{C}$ for $30 \mathrm{~s}, 50{ }^{\circ} \mathrm{C}$ for $1 \mathrm{~min}$ and $72{ }^{\circ} \mathrm{C}$ for $1.5 \mathrm{~min}$, and a final extension at $72{ }^{\circ} \mathrm{C}$ for $10 \mathrm{~min}$. DNA sequencing was performed at Beijing Genomics Institute, and the sequences were deposited in GenBank (Table 1).

\section{Phylogenetic analyses}

The molecular phylogeny was inferred from a combined dataset of ITS and nLSU sequences from 34 ingroup species and an outgroup species: Phlebia radiata $\mathrm{Fr}$. (Wu et al. 2010, Floudas \& Hibbett 2015). Most sequences were retrieved from open datasets and originated from Floudas \& Hibbett 2015. The sequences were aligned using the ClustalX v.1.83 (Chenna et al. 2003). Alignments were optimized manually in BioEdit v.7.0.5.3 (Hall 1999). Sequence alignment was deposited at TreeBase (http://treebase.org/treebase-web/home.html, submission ID 19563).

Maximum likehood (ML), Maximum parsimony (MP) and Bayesian inference (BI) analyses were conducted for the dataset. RAxML v.7.2.6 (Stamatakis 2006) was used for ML analysis. All parameters in the ML analysis used the default setting, and statistical support values were obtained using nonparametric bootstrapping with 1000 replicates (Hillis \& Bull 1993). MP analyses were performed using PAUP* 4.0b10 (Swofford 2002). Gaps in the alignments were treated as missing data. Trees were inferred using the heuristic search option with TBR branch swapping and 1000 random sequence additions. Max-trees were set to 5000 branches of zero length were collapsed, and all parsimonious trees were saved. Clade robustness was assessed using a bootstrap (BT) analysis with 1000 replicates (Felsenstein 1985). The tree length (TL), consistency indices (CI), retention indices (RI), rescaled consistency indices (RC) and homoplasy index (HI) were calculated for each tree generated. For Bayesian inference (BI), best models of evolution were estimated by using MrModeltest 2.2 (Nylander 2004), and posterior probabilities (BPP) were determined by Markov Chain Monte Carlo sampling (BMCMC) in MrBayes 3.1.2 (Ronquist \& Huelsenbeck 2003), using the estimated model of evolution. Four simultaneous Markov chains were run for $1,000,000$ generations, and trees were sampled every 100th generation. A majority rule consensus tree of all remaining trees was calculated.

\section{Results}

\section{Phylogenetic analyses}

The combined dataset had an aligned length of 2003 characters, of which 345 are parsimony-informative. MP analysis yielded four equally parsimonious trees $(\mathrm{TL}=1661, \mathrm{CI}=$ $0.499, \mathrm{RI}=0.632, \mathrm{RC}=0.315, \mathrm{HI}=0.501)$. The best model estimated and applied in the Bayesian analysis was a GTR $+\mathrm{I}+\mathrm{G}$ model. BI and ML analyses resulted in a topology similar to that with MP analysis. Only the ML tree is provided in Fig. 1 with the BT values $(\geq 50 \%)$ and BPPs $(\geq 0.95)$ are shown at the nodes. In the tree, species of Phanerochaete, Rhizochaete Gresl., Nakasone \& Rajchenb., Phaeophlebiopsis D. Floudas \& Hibbett and Phlebiopsis Jülich formed four independent 
Table 1 Taxa and GenBank accession numbers for ITS and nLSU sequences used in the phylogenetic analyses.

\begin{tabular}{|c|c|c|c|}
\hline \multirow{2}{*}{ Species } & \multirow{2}{*}{ Sample no. } & \multicolumn{2}{|c|}{ GenBank accession no. } \\
\hline & & ITS & nLSU \\
\hline Bjerkandera adusta & HHB-12826-Sp & KP134983 & KP135198 \\
\hline Phaeophlebiopsis caribbeana & HHB-6990 & KP135415 & KP135243 \\
\hline Phaeophlebiopsis peniophoroides & FP-150577 & KP135417 & KP135273 \\
\hline Phaeophlebiopsis sp. & HHB-6542-Sp & KP135413 & KP135413 \\
\hline Phanerochaete arizonica & RLG-10248-Sp & KP135170 & KP135239 \\
\hline Phanerochaete australis & HHB-7105-Sp & KP135081 & KP135240 \\
\hline Phanerochaete brunnea & He1873 & $\mathrm{KX} 212220^{\mathrm{a}}$ & $\mathrm{KX} 212224^{\mathrm{a}}$ \\
\hline Phanerochaete burtii & HHB-4618 & KP135117 & KP135241 \\
\hline Phanerochaete carnosa & HHB-9195-Sp & KP135129 & KP135242 \\
\hline Phanerochaete chrysosporium & HHB-6251-Sp & KP135094 & KP135246 \\
\hline Phanerochaete citrinosanguinea & FP-105385 & KP135100 & KP135234 \\
\hline Phanerochaete ericina & HHB-2288 & KP135167 & KP135247 \\
\hline Phanerochaete laevis & HHB-15519-Sp & KP135149 & KP135249 \\
\hline Phanerochaete magnoliae & HHB-9829-Sp & KP135089 & KP135237 \\
\hline Phanerochaete porostereoides & He1902 & $\mathrm{KX} 212217^{\mathrm{a}}$ & $\mathrm{KX} 212221^{\mathrm{a}}$ \\
\hline Phanerochaete porostereoides & He1908 & $\mathrm{KX} 212218^{\mathrm{a}}$ & $\mathrm{KX} 212222^{\mathrm{a}}$ \\
\hline Phanerochaete pseudomagnoliae & PP-25 & KP135091 & KP135250 \\
\hline Phanerochaete pseudosanguinea & FD-244 & KP135098 & KP135251 \\
\hline Phanerochaete rhodella & FD-18 & KP135187 & KP135258 \\
\hline Phanerochaete sanguinea & HHB-7524 & KP135101 & KP135244 \\
\hline Phanerochaete sanguineocarnosa & FD-359 & KP135122 & KP135245 \\
\hline Phanerochaete sordida & FD-106 & KP135070 & KP135253 \\
\hline Phanerochaete stereoides & $\mathrm{He} 2309$ & $\mathrm{KX} 212219^{\mathrm{a}}$ & $\mathrm{KX} 212223^{\mathrm{a}}$ \\
\hline Phanerochaete stereoides & Wu9708-118 & - & GQ470661 \\
\hline Phanerochaete subceracea & FP-105974-R & KP135162 & KP135255 \\
\hline Phanerochaete velutina & Kotiranta 25567 & KP994354 & KP994387 \\
\hline Phlebia radiata & AFTOL-484 & AY854087 & AF287885 \\
\hline Phlebiopsis crassa & KKN-86-Sp & KP135394 & KP135215 \\
\hline Phlebiopsis flavidoalba & FD-263 & KP135402 & KP135271 \\
\hline Phlebiopsis gigantea & FP-70857-Sp & KP135390 & KP135272 \\
\hline Phlebiopsis sp. & FP-102937 & KP135391 & KP135270 \\
\hline Porostereum spadiceum & Wu 9708-104 & - & DQ679918 \\
\hline Rhizochaete americana & FP-102188 & KP135409 & KP135277 \\
\hline Rhizochaete filamentosa & HHB-3169-Sp & KP135410 & KP135278 \\
\hline Rhizochaete radicata & FD-123 & KP135407 & KP135279 \\
\hline Rhizochaete sp. & FP-150712 & KP135408 & KP135280 \\
\hline Terana caerulea & FP-104073 & KP134980 & KP135276 \\
\hline
\end{tabular}

${ }^{\text {a }}$ Sequences newly generated in this study

clades with strong supports (Fig. 1). The two new collections of Phanerochaete porostereoides formed a highly supported lineage within the Phanerochaete clade. 


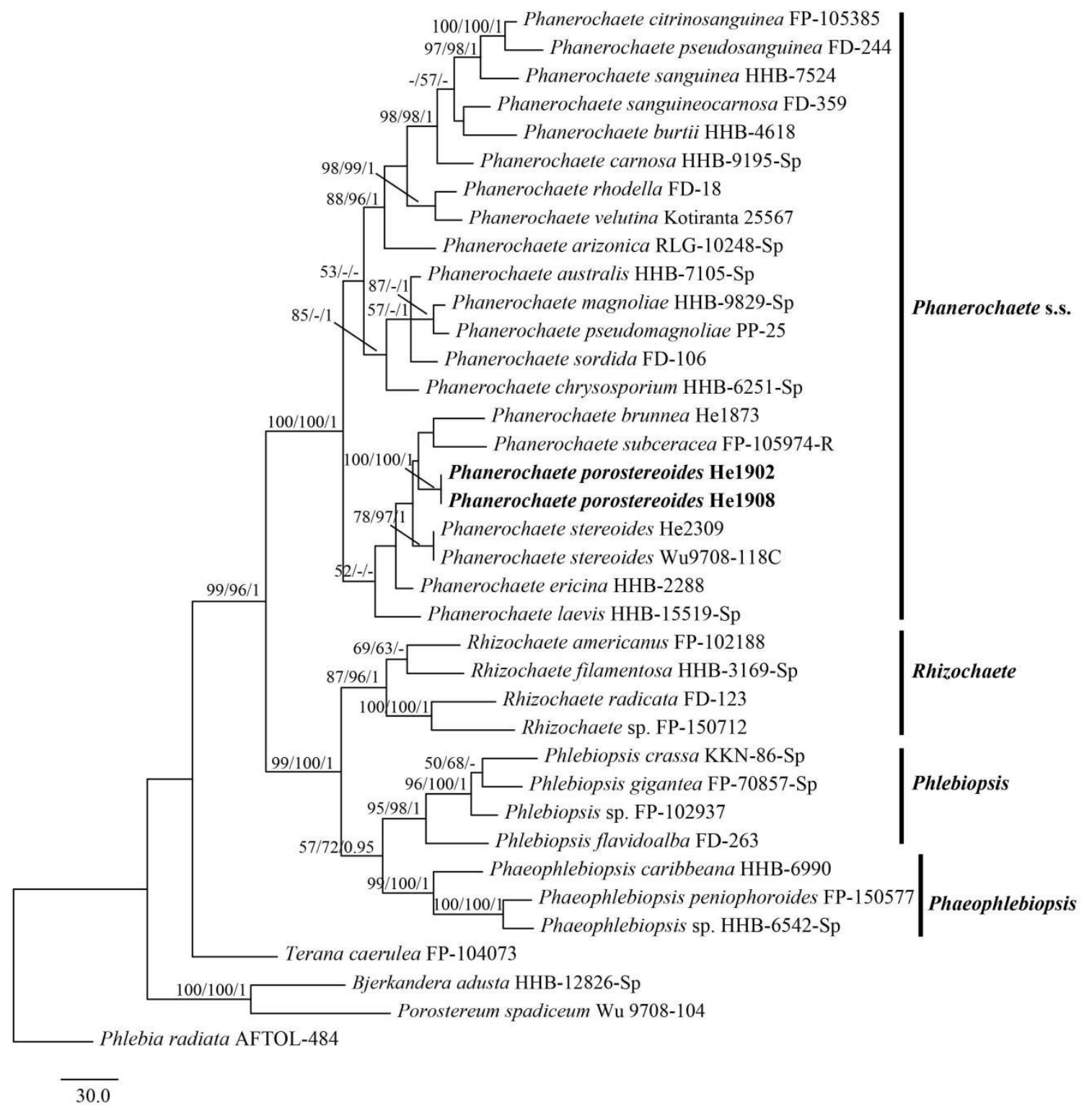

Fig. 1 - Phylogeny of Phanerochaete porostereoides and taxa in Phanerochaete s.l. and related genera generated by maximum parsimonious analysis based on combined ITS and nLSU sequences. Branches are labeled with maximum likelihood bootstrap value higher than 50\%, parsimony bootstrap value higher than $50 \%$, and Bayesian posterior probabilities more than 0.95 .

Phanerochaete porostereoides S.L. Liu \& S.H. He, sp. nov.

Figs $2-3$ MycoBank 817074

Facesoffungi number: FoF 02625

Type - China, Shannxi Province, Foping County, Foping Nature Reserve, on dead angiospermous tree, 11 September 2013, He 1908 (BJFC016375, holotype).

Etymology - "porostereoides" (Lat.) refers to the morphological resemblance to Porostereum.

Fruiting body - Basidiocarps annual, adnate, effused to slightly effused-reflexed, coriaceous, leathery to soft corky, first as small round patches, later confluent up to $15 \mu \mathrm{m}$ long, up to $200 \mu \mathrm{m}$ thick. Hymenial surface smooth or tuberculate with scattered tubercles, light brown [6D(5-8)], brown [6E(5-8)] to dark brown [6F(5-8)], unchanged in $\mathrm{KOH}$, not cracked or slightly cracked with age; margin thinning out, white $(6 \mathrm{~A} 1)$, orange $[6 \mathrm{~A}(6-7)]$ to brownish orange $[6 \mathrm{C}(4-$ 8)] when juvenile, becoming concolorous with hymenial surface when mature, usually slightly lifted and curved inward, up to $2 \mathrm{~mm}$ wide. 

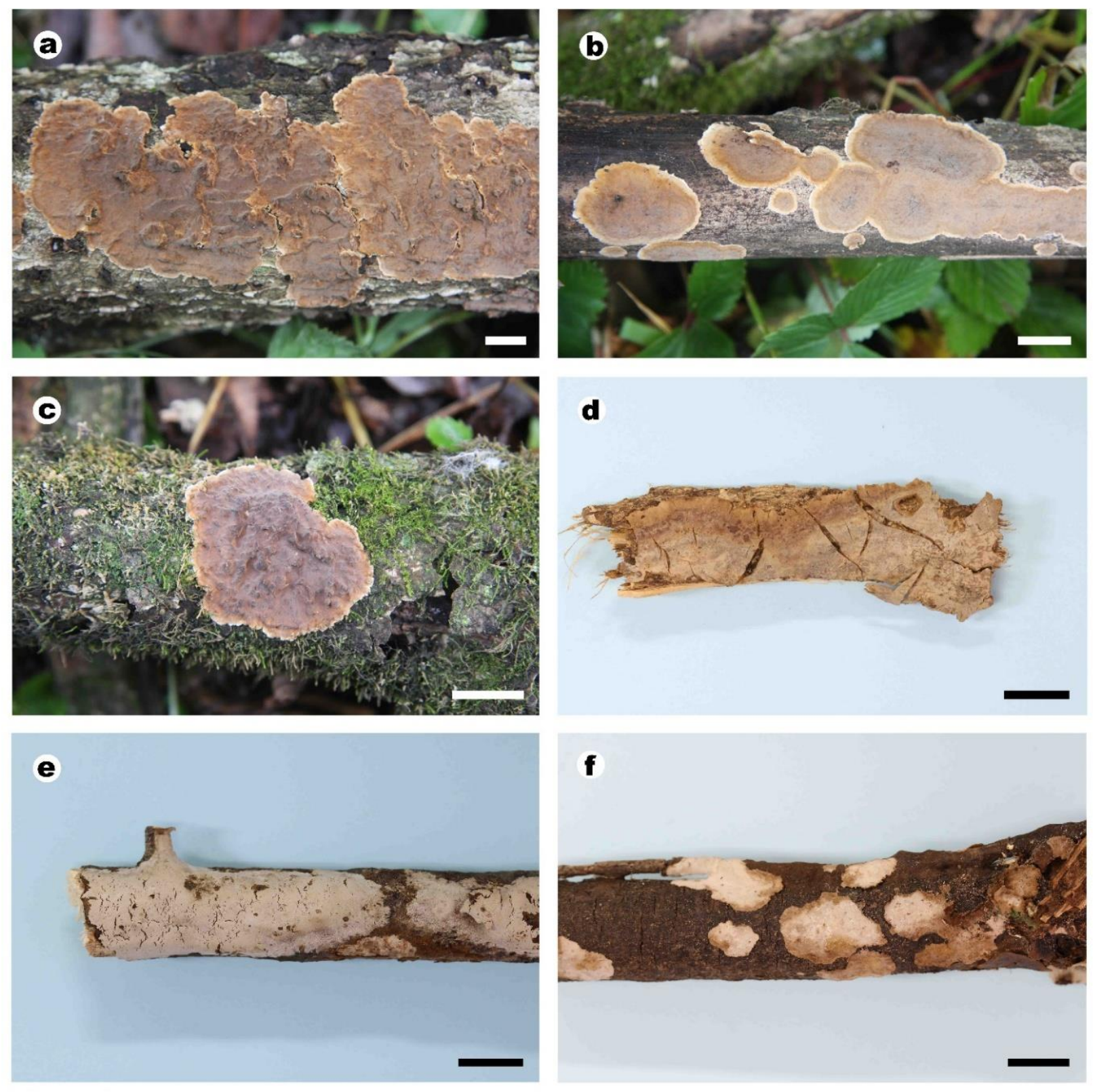

Fig. 2 - Basidiocarps of Phanerochaete species with brown subicular hyphae. a-c. $P$. porostereoides (a. holotype He 1908, b-c paratype He 1902). d. P. monomitica (F8333). e. $P$. brunnea (He 1873). f. P. stereoides (He 2309). Bars $=10 \mu \mathrm{m}$.

Hyphal structure - Hyphal system monomitic, all hyphae without clamps, not darkening in $\mathrm{KOH}$. Subiculum well developed, subicular hyphae yellowish brown, thick-walled, moderately branched at right angles, more or less parallel to substrate, 3-7 (10) $\mu \mathrm{m}$ in diam. Subhymenium indistinct, hyphae in this layer similar to subicular hyphae.

Hymenium - Hyphal ends scattered to numerous, thick-walled, yellowish brown, originated from subiculum, with blunt tips, not projecting outside of hymenium. Cystidia and cystidioles absent. Basidia scattered to rare, clavate, hyaline, thin-walled, with a basal simple septum and four sterigmata, 23-35 $\times 4-5.3 \mu \mathrm{m}$; basidioles numerous, similar basidia but slightly smaller.

Spores - Basidiospores ellipsoid, hyaline, thin-walled, smooth, IKI-, CB-, (4.5-)4.7-5.3($5.5) \times(2.3-) 2.5-3.1(-3.3) \mu \mathrm{m}, \mathrm{L}=4.98 \mu \mathrm{m}, \mathrm{W}=2.85 \mu \mathrm{m}, \mathrm{Q}=1.76(\mathrm{n}=60 / 2)$. 

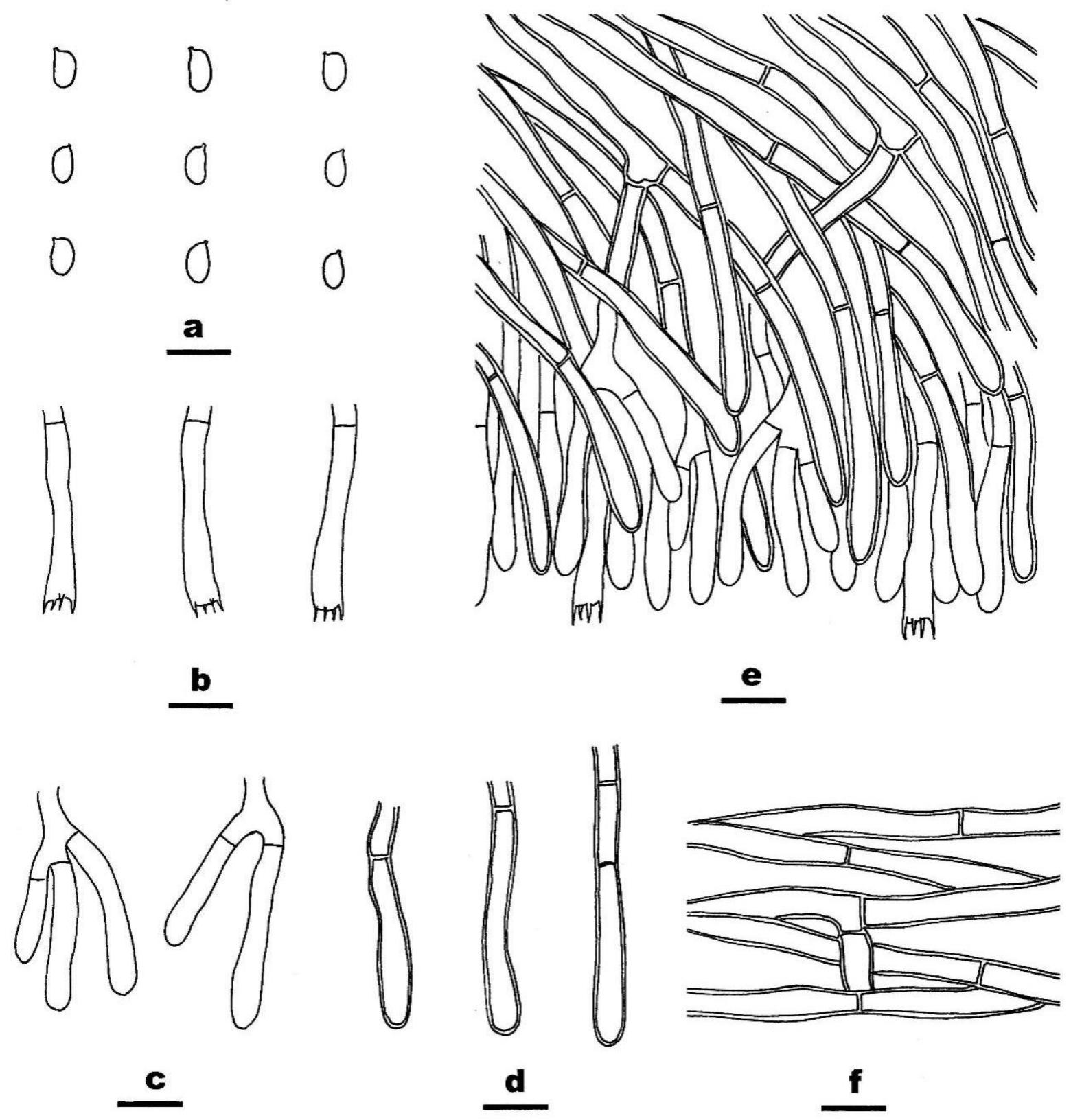

Fig. 3 - Microscopic structures of Phanerochaete porostereoides (holotype, He 1908), a. Basidiospores. b. Basidia. c. Basidioles. d. hyphal ends from hymenium. e. Section through part of basidiocarp. f. Generative hyphae from subiculum. Bars $=10 \mu \mathrm{m}$.

Additional specimens examined - Phanerochaete porostereoides: China, Shaanxi Province, Foping County, Foping Nature Reserve, on dead angiospermous tree, 11 September 2013, He 1902 (BJFC016369, paratype). Phanerochaete monomitica: Argentina, Corrientes, Ituzaingó, Isla Apipé Grande, Monte Grande, interior de selva, 26 September 1988, leg. O. Popoff et al. 602 (F8332, TNM); Capital, Richuelo, en selva degradada, 28 September 1990, leg. O. Popoff et al. 729 (F8333, TNM). Paraguay, Itapúa, Alto paran, Reserva Biol. Itabó, $6 \mathrm{~km} \mathrm{~N}$ de la Administractión, interior de la selva, 9 October 1990, leg. O. Popoff \& Caballero 800 (F8331, TNM). Phanerochaete brunnea: China, Zhejiang Province, Qingyuan County, Baishanzu Nature Reserve, on fallen angiospermous branch, 15 August 2013, He 1873 (BJFC 16340). Phanerochaete stereoides: China, Hunan Province, Zhangjiajie County, Zhangjiajie Forest Park, on fallen angiospermous branch, 8 July 2015, He 2309. 


\section{Discussion}

Five species of Phanerochaete, P. brunnea Sheng H. Wu, P. fuscomarginata (Burt) Gilb., P. monomitica (G. Cunn.) Sheng H. Wu \& Popoff, P. singularis and P. stereoides, with brown subicular hyphae were accepted by Wu (1995). However, Hjortstam and Ryvarden (2002) established a new genus, Australicium Hjortstam \& Ryvarden, to accommodate Corticium singulare G. Cunn., and referred P. fuscomarginata and P. monomitica to Porostereum. In our phylogenetic tree, $P$. brunnea, $P$. stereoides and $P$. porostereoides described above nested within the Phanerochaete s.s. clade (Fig. 1). Thus, we would like to keep them all in Phanerochaete.

Phanerochaete porostereoides is similar to $P$. monomitica, both of which resemble Porostereum and have brown hymenial surface, simple septate and brown generative hyphae, and hyphal ends in hymenium and subhymenium. However, $P$. monomitica differs from $P$. porostereoides by its larger basidospores $(6-7 \times 3.5-4.5 \mu \mathrm{m}$, Hjortstam \& Ryvarden 1990; 6-7.3 $\times$ 3.8-4.6 $\mu \mathrm{m}$, measured by the authors from F8333 in TNM, Fig. 2d) and distribution in the South Hemisphere (New Zealand, Argentina and Paraguay, Wu 1995). Phanerochaete porostereoides is also reminiscent of Porostereum perplexum (D.A. Reid) Hjortstam \& Ryvarden, which however is reported only from the type locality in Australia and has distinctly larger basidiospores $(6.5-10 \times$ 3-3.5 $\mu \mathrm{m}$, Hjortstam \& Ryvarden 1990).

Phanerochaete brunnea Sheng H. Wu reported from Taiwan was considered as a synonym of Australicium singulare (G. Cunn.) Hjortstam \& Ryvarden (Hjortstam \& Ryvarden 2002). However, according to Wu (1995), P. brunnea has smaller basidiospores than A. singulare. A specimen (He 1873, Fig. 2e) collected from southeastern China has basidiospores measured as 4-5 $\times 2-3 \mu \mathrm{m}$, which is in the range of spore size of $P$. brunnea. We identified it as $P$. brunnea, and this is the first report of $P$. brunnea from mainland China. At present, we would like to accept $P$. brunnea as an independent species before more evidence show that it is conspecific with $P$. singularis. $P$. brunnea can be easily distinguished from $P$. porostereoides by its basidiocarp texture, color of hymenial surface and the anatomical structure (Wu 1990, 1995).

Phanerochaete stereoides (Fig. 2f) reported from China (Wu 1995, Xiong \& Dai 2009) differs from $P$. porostereoides in pale grayish-brown hymenial surface, presence of cystidia, and larger basidiospores $(6.5-8 \times 3.2-4 \mu \mathrm{m}$, Wu 1995). Meanwhile, $P$. stereoides and $P$. porostereoides formed two distinct linages in the phylogenetic tree (Fig. 1). Phanerochaete hyphocystidiata Sheng $\mathrm{H}$. Wu resembles $P$. porostereoides by having hyphal ends in hymenium and subhymenium and same size of basidiospores, but the former has hyaline subicular hyphae (Wu 1998).

Although the Phanerochaete s.s. clade got high support in the phylogenetic tree (100/100/1, Fig. 1), species of this clade sampled in this study show high morphological diversity. For example, hyphal cords, clamp connections and cystidia can be present or totally absent among the species. Meanwhile, it seems that the brown color of the subicular hyphae and hymenial surface is phylogenetically unimportant. Thus, in future, some other characters like chemical reactions should be used, and more species are needed to be sequences to resolve the generic positions of many species in Phanerochaete s.l.

\section{Acknowledgements}

The authors would like to express their deep appreciation to Drs. Karen Nakasone (Center for Forest Mycology Research, U.S. Forest Service) and Yu-Cheng Dai (Beijing Forestry University, China) for their suggestion in preparing the manuscript. Special thanks are due to Dr. Sheng-Hua $\mathrm{Wu}$ (National Museum of Natural Science, Taiwan) for specimen loans and confirmation of the new species. The research was supported by the Fundamental Research Funds for the Central Universities (NO. 2016ZCQ04).

\section{References}

Bernicchia A, Gorjón SP. 2010 - Fungi Europaei 12. Corticiaceae s.l. Edizioni Candusso, Alassio. pp. 489-508. 
Burdsall HH Jr. 1985 - A contribution to the taxonomy of the genus Phanerochaete. Mycologia Memoirs 10, 1-165.

Chenna R, Sugawara H, Koike T, Lopez R, Gibson TJ, Higgins DG, Thompson JD. 2003 Multiple sequence alignment with the Clustal series of programs. Nucleic Acids Research 31, 3497-3500.

de Koker T, Nakasone KK, Haarhof J, Burdsall HH Jr., Janse BJH. 2003 - Phylogenetic relationships of the genus Phanerochaete inferred from the internal transcribed spacer region. Mycological Research 107, 1032-1040.

Eriksson J, Hjortstam K, Ryvarden L. 1978 - The Corticiaceae of North Europe vol. 5: Mycoaciella-Phanerochaete. Fungiflora, Oslo, pp 987-1047.

Felsenstein J. 1985 - Confidence intervals on phylogenetics: an approach using bootstrap. Evolution 39, 783-791.

Floudas D, Hibbett DS. 2015 - Revisiting the taxonomy of Phanerochaete (Polyporales, Basidiomycota) using a four gene dataset and extensive ITS sampling. Fungal Biology 119, 679-719.

Hall TA. 1999 - Bioedit: a user-friendly biological sequence alignment editor and analysis program for Windows 95/98/NT. Nucleic Acids Symposium Series 41, 95-98.

Hillis DM, Bull JJ. 1993 - An empirical test of bootstrapping as a method for assessing confidence in phylogenetic analysis. Syst Biodivers 42, 182-192.

Hjortstam K, Ryvarden L. 1990 - Lopharia and Porostereum (Corticiacae). Synopsis Fungorum 4, $1-68$.

Hjortstam K, Ryvarden L. 2002 - Australicium (Basidiomycotina, Aphyllophorales), a new genus for Corticium singulare G. Cunn. Synopsis Fungorum 15, 18-21.

Kornerup A, Wanscher JH. 1978 - Methuen handbook of colour. 3rd Ed. E. Methuen and Co., Ltd., London. pp 1-252.

Nylander JAA. 2004 - MrModeltest v2. Program distributed by the author. Evolutionary Biology Centre, Uppsala University.

Ronquist F, Huelsenbeck JP. 2003 - MRBAYES 3: bayesian phylogenetic inference under mixed models. Bioinformatics 19, 1572-1574.

Stamatakis A. 2006 - RAxML-VI-HPC: maximum likelihood-based phylogenetic analyses with thousands of taxa and mixed models. Bioinformatics 22, 2688-2690.

Swofford DL. 2002 - PAUP*: Phylogenetic analysis using parsimony (*and other methods). Version 4.0b10. Sinauer Associates, Sunderland, Massachusetts.

White TJ, Bruns T, Lee S, Taylor J. 1990 - Amplification and direct sequencing of fungal ribosomal RNA genes for phylogenetics. In: Innis MA, Gelfand DH, Sninsky JJ, White TJ (eds.), PCR Protocols: A guide to methods and applications. Academic Press, San Diego, pp 315-322.

Wu SH, Nilsson HR, Chen CT, Yu SY, Hallenberg N. 2010 - The white-rotting genus Phanerochaete is polyphyletic and distributed throughout the phlebioid clade of the Polyporales (Basidiomycota). Fungal Diversity 42, 107-118.

Wu SH. 1990 - The Corticiaceae (Basidiomycetes) subfamilies Phlebioideae, Phanerochaetoideae and Hyphodermoideae in Taiwan. Acta Botanica Fennica 142, 1-123.

Wu SH. 1995 - A study of the genus Phanerochaete (Aphyllophorales) with brown subicular hyphae. Mycotaxon 54, 163-172.

Wu SH. 1998 - Nine new species of Phanerochaete from Taiwan. Mycological Research 102, $1126-1132$.

Xiong HX, Dai YC. 2009 - Notes on lignicolous corticioid fungi in China 3. Phanerochaete (Basidiomycota, Polyporales) in China. Mycosystema 28, 29-35. 